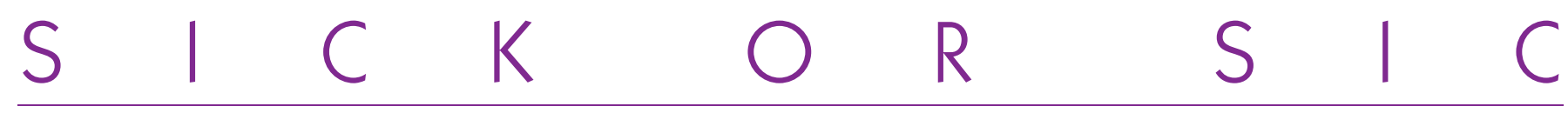

\title{
EVIDENCE AND ORTHODONTICS
}

\section{Michel AMORIC}

The relationship between English and French is complicated by the abundance of false cognates found in each language. The word evidence, first appears in the XIV th century, in both French and English literature and means: that which becomes visually apparent (from the Greek $\varepsilon 1 \delta \omega$, or from Latin ex-videre "to see"); that which is perceived; that which is grasped by the mind; that which is obvious, indisputable, clear, patent.

\section{IN ENGLISH}

The term evidence evolved over the centuries and became synonymous with proof, testimony, etc.:

- evidence to support;

- there is no evidence that...;

- evidence against...;

- to produce something as evidence;

- he tried to destroy the evidence;

- to give evidence.

The term Evidence-Based (Dental) Medicine appeared in Canada in the 80s. (EBM) aims to apply the best available evidence gained from the scientific method to clinical decision making. It developed from a desire to improve public health policy by benchmarking "best practices". Online catalogs select and analyze medical articles that are particularly pertinent due to their rigorous methodology.

In the field of dentistry, very few articles were accepted for the online catalogs because of bias in the choice of articles, the varying skill levels of the practitioners and the socio-economic setting of their practices.

However, if the advantages of our expertise are not always appreciated out of context, our accumulated knowledge is still an irreplaceable source of support to our patients who expect reliably safe therapy and accurate diagnosis based on well supported information. 
IN FRENCH

For French speakers, évident means obvious, that which is considered to be true without question:

Vérité évidente. An obvious truth/ self-evident truth.

" II nous est plus évident qu'une religion doit adoucir les mours des hommes, qu'il ne l'est qu'une religion soit vraie." "

Montesquieu, L'Esprit des lois, XXIV, 4.

"For it is more obvious that religion ought to humanize the manners of men than that any particular religion is true."

Montesquieu, The Spirit of the Laws, XXIV, 4.

The reasoning is simple and logical, the word evident in French becomes a rhetorical device in both discursive and polemic argumentation. Why contest something when it is presented as a self-evident truth?

$$
\text { ** }
$$

If Evidence-Based (Dental) Medicine is open to criticism, the use of the word evidence, in the context of our professional debates, can be misleading.

\section{First example}

1) When teeth first appear in the arch, they are driven by an eruptive force (irrefutable fact).

2) The mandibular teeth are frequently subject to crowding during the same period of time that the wisdom teeth are erupting, (second irrefutable fact).
Conclusion: it's obvious that the eruption of wisdom teeth causea crowding of incisors!

However, the assertion is false because certain factors associated with crowding have been omitted: crowding can result from late eruption of the canines... Crowding can also occur in the absence of wisdom teeth or when premolar teeth are congenitally missing, etc.

\section{Second example}

Treating an anomaly before it fully develops is a self-evident truth. But, once more, the omission of certain factors related to the anomaly, disqualifies this categorical assertion: Quid/What about the psychological fatigue the patient experiences as a result of the overall length of excessive treatment? Quid spontaneous remissions that occur with certain problems? etc.

These two examples show that by consciously or unconsciously hiding certain factors involved, it is possible to persuade the listener of the irrefutability of the evidence regardless of whether it's actually true or not.

Evidence-Based (Dental) Medicine relies on the use of formal statisticbased methods of treatment that are recognized and shared by the entire scientific community. EBM still has some negatives; i.e., it is difficult to read, it is incomplete, it presents information out of context and, it doesn't recognize our specialty as an art as well as a discipline. 
Evidence, however, similar to logical argumentation, is not free of ambiguity, errors and defects.

We should be wary of statements that appear to be self-evident: selfevident bad faith, obvious untruths!

- Amoric M. Décisions et choix thérapeutiques en orthodontie. Encyclopédie Médico-Chirurgicale, Elsevier, 2011;28-610-K10.

- Davidoff F, Haynes RB, Sackett DL, Smith R. Evidence-based medicine. British Medical Journal 1995;310: 1085-6.

- Melsen B, Current controversies in orthodontics, Chicago: Quintessence International, 1991.

- Naylor CD, Grey zones of clinical practice: some limits to evidence- based medicine. Lancet 1995; 345:840-2.

- Perelman C, L'Empire rhétorique, Paris : Vrin, 1977.

- Rinchuse DJ, Rinchuse DJ, Kandasamy S, Ackerman MB. Deconstructing evidence in orthodontics: making sense of systematic reviews, randomized clinical trials, and meta-analyses. World J Orthod 2008 Summer;9(2):167-76.

- Sackett DL, et al. Evidence based medicine: what it is and what it isn't. BMJ 1996;312(7023): 71-2.

- Sharon E, et al. La médecine fondée sur les faits. Evidencebased medicine, Elsevier, Coll. Médecine en poche, en français, ( $1^{\text {re }}$ édition) 2007. 